http://dx.doi.org/10.12775/szhf.2015.021

\title{
Historyczne uwarunkowania rozwoju logicznego empiryzmu i ahistoryczność jego dotychczasowej krytyki
}

\author{
Wprowadzenie
}

Logiczny empiryzm był prądem umysłowym, który odcisnął wielkie piętno na umysłowości XX-wiecznej. Ruch ten, ze względu na szerokie spektrum poruszanej tematyki i ambicje reformatorskie na polu naukowym i społecznym był niezwykle złożonym zjawiskiem w dziejach myśli ludzkiej. Już sama jego nazwa jest kłopotliwa ${ }^{1}$. Aby uniknąć omawiania wielu stanowisk definicyjnych, przyjmuję jedną wspólną nazwę - logiczny empiryzm - dla

${ }^{1}$ Logiczny empiryzm swoje korzenie intelektualne miał w filozofii pozytywistycznej. Poprzedzały go filozofia klasycznego pozytywizmu, kojarzona z A. Comte'em i empiriokrytycyzm E. Macha. W stosunku do trzeciego pozytywizmu, często używa się zamiennie nazw - „logicznego pozytywizmu” i „logicznego empiryzmu”, by podkreślić znaczenie logicyzmu w kształtowaniu jego głównych założeń. W stosunku do obu tych określeń w polskiej literaturze utrwaliła się nazwa - „neopozytywizm”. Jednak wobec całego nurtu neopozytywistycznego, najczęściej używanym w literaturze określeniem jest - „logiczny empiryzm”. Zostało ono wypracowane przez empirystów berlińskich pracujących pod kierunkiem Hansa Reichenbacha, którzy chcieli się wyróżnić na tle Koła Wiedeńskiego, którego idee rozwijali. Z czasem te niuanse terminologiczne rozmyły się, a terminu „logiczny empiryzm” zaczęto używać dla określenia całości dorobku neopozytywizmu. W artykule tym będę używał zamiennie dwóch nazw - „logicznego empiryzmu” i „neopozytywizmu”, mając na myśli ten sam nurt. 
uczonych, przekonanych o tym, że głównym źródłem wiedzy naukowej jest doświadczenie, a zdobyta $w$ ten sposób wiedza funkcjonuje w ramach języka, który powinien być jak najbardziej ścisły i jednoznaczny.

Krytycy logicznego empiryzmu przedstawiali ten nurt jako system filozoficzny, arbitralnie uznając jego przedstawicieli za wysoce koherentną grupę doktrynerów dążących do przebudowy społeczeństwa zgodnie z wyznawanym przez nich ideałem naukowego światopoglądu ${ }^{2}$. Ocena taka zdominowała opracowania z zakresu historii filozofii. Współcześnie, zwłaszcza w Europie Zachodniej, niekorzystny obraz tego nurtu został zrehabilitowany głównie dzięki działalności Instytutu Koła Wiedeńskiego przy Uniwersytecie Wiedeńskim ${ }^{3}$. Na gruncie filozofii polskiej rehabilitacji tego nurtu podjął się Artur Koterski, który oprócz szeroko zakrojonej działalności translatorskiej i wydawniczej, zaproponował w swych pracach nowe spojrzenie na problem oceny logicznego empiryzmu ${ }^{4}$. Autor ten poruszył problem wpływu liberalnej atmosfery Wiednia z początków XX wieku na rozwój Koła Wiedeńskiego oraz jego oddziaływanie na szerszy problem demarkacji wiedzy naukowej.

Przeprowadzenie rzetelnej oceny tego nurtu ma kluczowe znaczenie, zważywszy na jego silne oddziaływanie na XX-wieczną filozofię nauki. Celem artykułu jest poddanie analizie historycznej głównych założeń tego kierunku w odniesieniu do realiów historycznych, w których zostały ukształtowane. Uzupełnienie dyskusji o te realia może rzucić nieco światła na rozumienie tego, czym w rzeczywistości był logiczny empiryzm.

\section{Źródła i cele logicznego empiryzmu}

Poglądy logicznych empirystów kształtowały się jako odpowiedź na problemy trapiące naukę, gospodarkę, społeczeństwo, politykę i inne obszary życia publicznego Europy początków XX wieku. Uczeni o filozoficznym

\footnotetext{
${ }^{2}$ Logiczni empiryści, przeciwni wszelkim systemom i szkołom filozoficznym, swoje postulaty niechętnie określali mianem filozofii, lecz woleli je nazywać naukowym światopoglądem. Zob. Naukowa koncepcja świata. Koło Wiedeńskie, pod red. H. Hahna, O. Neuratha, R. Carnapa, przeł. A. Koterski, [w:] Naukowa koncepcja świata. Koło Wiedeńskie, pod red. A. Koterskiego, Gdańsk 2010.

${ }^{3}$ Instytut ten, nawiązując do tradycji Koła Wiedeńskiego, prowadzi działalność publikacyjną i edukacyjną, kontynuując i rozwijając spuściznę intelektualną logicznego empiryzmu.

${ }^{4}$ Zob. A. Koterski, Geneza i cel naukowej koncepcji świata, [w:] Naukowa koncepcja świata...; tenże, Weryfikacjonistyczne kryteria demarkacji w filozofii nauki Koła Wiedeńskiego, UMCS, Lublin 2001.
} 
nastawieniu do nauki spotykali się już od 1907 roku w wiedeńskich kawiarniach. Z czasem zebrania te nabrały cyklicznego charakteru: odbywały się w każdy czwartek, w ramach seminariów prowadzonych na Uniwersytecie Wiedeńskim przez Moritza Schlicka. Grupę tę nazwano później Kołem Wiedeńskim ${ }^{5}$. Owocem tych dyskusji była publikacja w 1929 roku manifestu, wyrażającego naukowy światopogląd tej grupy ${ }^{6}$.

Logiczny empiryzm, będący owocem liberalnej atmosfery Wiednia początków XX wieku ${ }^{7}$, wywarł wielki wpływ na umysłowość XX-wieczną, zwłaszcza na gruncie filozofii i nauk przyrodniczych. Źródłami jego inspiracji były klasyczny empiryzm, zwłaszcza jego nurt sceptyczny rozwijany przez Davida Hume' ${ }^{8}$ oraz logicyzm ${ }^{9}$, rozwijany na przełomie XIX i XX wieku

${ }^{5}$ Zagadnienie początków Koła Wiedeńskiego omówili już H. Buczyńska-Garewicz, Koło Wiedeńskie, Toruń 1993; A. Koterski, Geneza i cel naukowej koncepcji...; W. Sady, Spór o racjonalność naukową. Od Poincarego do Laudana, Funna, Wrocław 2000. Na seminariach Schlicka najwięcej uwagi poświęcano analizie traktatu logiczno-filozoficznego Ludwiga Wittgensteina, który uznawany jest za inspiratora całego ruchu. L. Wittgenstein, Tractatus Logico-Philosophicus, przeł. B. Wolniewicz, wyd. 3, Warszawa 2000. Ta niewielka książeczka stała się dla członków Koła dziełem podstawowym, choć sam Wittgenstein nigdy członkiem Koła nie był.

${ }^{6}$ Naukowa koncepcja świata. Koło Wiedeńskie, pod red. H. Hahna, O. Neuratha, R. Carnapa, przeł. A. Koterski, [w:] Naukowa koncepcja świata..., s. 77-78. Logiczni empiryści nie byli zawodowymi filozofami. Mieli wykształcenie kierunkowe z zakresu matematyki, fizyki, historii, ekonomii, psychologii, prawa. Odznaczali się jednak filozoficznym zacięciem, które $\mathrm{w}$ połączeniu z żywym zainteresowaniem aktualną sytuacją $\mathrm{w}$ nauce, gospodarce i życiu społecznym zaowocowały wiarą, że XX-wieczna nauka oczyszczona z metafizyki i zabobonów może przyczynić się do poprawy losu ludzkości.

${ }^{7}$ Problem wpływu atmosfery intelektualnej Wiednia na ukształtowanie się programu Koła Wiedeńskiego podjął A. Koterski, Geneza i cel naukowej.... Autor zwrócił szczególną uwagę na tradycję badań empirycznych na Uniwersytecie Wiedeńskim oraz liberalną atmosferę wielokulturowego Wiednia.

${ }^{8}$ Jak każdy prąd umysłowy, logiczny empiryzm wywodzi się z określonej tradycji. W szerokim kontekście historycznym możemy go umiejscowić w tradycji epistemologicznej empiryzmu. Zawężając ten kontekst, i skupiając się na poruszanych zagadnieniach, logiczny empiryzm możemy umieścić w nurcie pozytywizmu. Wątków inspirujących pozytywizm można się doszukiwać już w średniowiecznej filozofii Rogera Bacona i Wilhelma Ockhama. Jednak większość badaczy zgodnie uznaje Dawida Hume’a za protoplastę pozytywizmu i wyrosłego na jego gruncie logicznego empiryzmu.

${ }^{9}$ Wśród prądów, które ukształtowały naukowy światopogląd, członkowie Koła Wiedeńskiego wymieniali: 1) pozytywizm i empiryzm (David Hume, oświecenie, Auguste Comte, John S. Mill, Richard Avenarius, Ernst Mach); 2) Dzieła współczesnych im uczonych mających szczególny wpływ na naukę (Bernhard Riemann, Hermann von Hemholtz, Ernst Mach, Henri Poincare, Pierre Duhem, Ludwig Boltzmann, Albert Einstein); 3) Logicyzm (Gottfried W. Leibniz, Giuseppe Peano, Gottlob Frege, Bertrand Russell, Alfred N. Whitehead, L. Witt- 
w odpowiedzi na kryzys podstaw matematyki spowodowany niedającym się rozwiązać już od czasów starożytnych problemem samoodniesienia języka, w ramach którego zdanie próbuje orzekać samo o sobie.

Jakie cele stawiał sobie logiczny empiryzm opierający się na wspomnianych wyżej podstawach? Odpowiedź na tak postawione pytanie jest problematyczna, biorąc pod uwagę ogromny dorobek myślicieli odwołujących się do idei neopozytywistycznych. W swych pracach poruszali oni problemy z dziedziny logiki, etyki, epistemologii, psychologii, polityki, socjologii, religii i wielu innych dziedzin nauki. $Z$ tego względu konieczne jest określenie jednego centralnego punktu, do którego sprowadzały się wszystkie poruszane problemy.

Można przyjąć za L. Kołakowskim, że kluczowym zagadnieniem, wokół którego oscylowały rozważania logicznych empirystów, był problem wiedzy ludzkiej ${ }^{10}$. Zarówno Hume, jak i nawiązujący do niego neopozytywiści uczynili z wiedzy ludzkiej centralny punkt swych rozważań. Jednak byłoby nieuzasadnioną generalizacją utożsamianie empiryzmu sceptycznego i logicznego, gdyż oba nurty dzieliło blisko dwieście lat ewolucji nauki. Należy więc rozważyć historyczne okoliczności, w jakich rozwijały się oba nurty.

Hume prezentował swój program w okresie triumfów mechaniki Newtona, choć sam pozostawał wobec niej sceptyczny, zawłaszcza wobec metody indukcyjnej stosowanej przez Newtona i przyjętej przez niego „bezwiednie” zasady przyczynowości wymykającej się poznaniu na gruncie filozofii empirycznej ${ }^{11}$. Mimo tych niepokojów, przyszło Hume'owi żyć w czasach optymizmu poznawczego, który wyrażał się w przekonaniu, że ludzkość może zdobyć wiedzę pewną o zjawiskach świata fizycznego, a zadaniem filozofów powinno być dawanie wskazówek metodologicznych uczonym, poprzez stawianie pytań o to, co możemy wiedzieć w sposób pewny.

genstein); 4) Program aksjomatyzacji arytmetyki (David Hilbert, G. Peano); 5) Socjologia pozytywna (Epikur, D. Hume, Jeremy Bentham, Herbert Spencer, A. Comte). Por. Naukowa koncepcja świata..., s. 73-74.

${ }^{10}$ L. Kołakowski, Filozofia pozytywistyczna. Od Hume’a do Koła Wiedeńskiego, wyd. 2, Warszawa 2003, s. 10.

${ }^{11}$ Sam Newton na pytania o podstawę swych praw odpowiadał zdawkowo, że nie stawia hipotez: I. Newton, Matematyczne zasady filozofii przyrody, przeł. J. Wawrzycki, Kraków 2011, s. 694. Hume doszedł do wniosku, że jedynie wiedza dotycząca idei (bytów matematycznych i relacji między nimi) jest pewna. Natomiast wiedza dotycząca faktów ustalanych na drodze empirycznej jest niepewna. D. Hume, Badania dotyczące rozumu ludzkiego, przeł. D. Misztal, T. Sieczkowski, Kraków 2006, s. 52-53; 62-66. 
Logiczny empiryzm z kolei rozwijał się w okresie kryzysu nauki przełomu XIX i XX wieku. Matematykom nie dawały spokoju antynomie na gruncie teorii mnogości. Fizycy musieli zmierzyć się z kryzysem mechaniki klasycznej, spowodowanym rozwojem szczególnej teorii względności i teorii kwantów. Kryzys w fizyce był tym boleśniejszy, że uważano ją dotychczas za ideał naukowego wyjaśniania świata, do którego powinny dążyć inne nauki. Poczucie niepewności, towarzyszącej uczonym tamtego okresu scharakteryzował dobitnie Max Planck:

[...] Żyjemy w osobliwym świecie. Gdziekolwiek spojrzymy, we wszystkich dziedzinach kultury materialnej i duchowej stwierdzamy, że nastały czasy ciężkich kryzysów, wyciskających piętno niepokoju i niepewności, na całym naszym życiu prywatnym i publicznym [...]. Podobnie jak od dawna w religii i w sztuce, nie ma teraz również i w nauce żadnego aksjomatu, który by nie był przez kogoś kwestionowany, nonsensu, w który ktoś by nie wierzył [... $]^{12}$.

By ustanowić pewny punkt oparcia dla dorobku nauki początków XX wieku i odnaleźć rozsądek nie tylko na gruncie nauki, ale i w mnogości ideologii społeczno-politycznych, roszczących wówczas pretensje do miana naukowych, logiczni empiryści zaproponowali metodę analizy języka nauki, która weryfikowałaby sensowność twierdzeń naukowych.

Za pomocą metod logicznych i empirycznych, neopozytywiści chcieli ustanowić pewny fundament $\mathrm{w}$ dziedzinach, których aktualną kondycję dyskutowali. W ogłoszonym w 1929 roku manifeście zdefiniowali w czym przejawia się empiryzm ich czasów:

To właśnie metoda analizy logicznej w sposób zasadniczy odróżnia dzisiejszy empiryzm i pozytywizm od ich wersji wcześniejszej, będącej raczej ujęciem biologiczno-psychologicznym. Jeżeli ktoś twierdzi, że 'Bóg istnieje', 'pierwotną zasadą świata jest to, co nieświadome', 'istnieje entelechia, która jest naczelną zasadą żywych organizmów', to nie powiemy mu: 'to co mówisz jest fałszem', lecz pytamy, 'co rozumiesz przez swe wypowiedzi?'13.

Logiczni empiryści nie zadawali już pytań, które stawiali klasyczni empiryści: „Co można wiedzieć w sposób pewny?” Nie pytali o bezpośrednie

${ }^{12}$ M. Planck, Pozytywizm a realny świat zewnętrzny, przeł. R. i S. Kernerowie, [w:] M. Planck, Jedność fizycznego obrazu świata. Wybór pism filozoficznych, Książka i Wiedza, Warszawa 1970, s. 143.

${ }^{13}$ Naukowa koncepcja świata..., s. 77-78. 
źródła wiedzy. Woleli ograniczyć się do pytania: „Jaki sens ma twoja wypowiedź?" Tak postawione pytanie można było przynajmniej poddać analizie logicznej i ustalić ewentualną możliwość weryfikacji empirycznej takiego zdania.

\section{Główne zarzuty wobec logicznego empiryzmu}

Dotychczasową krytykę filozofii neopozytywistycznej można podzielić na dwa nurty. Pierwszy doszukiwał się niespójności w założeniach programu neopozytywistycznego, przedstawiając dorobek jego przedstawicieli jako pasmo pomyłek i nieporozumień ${ }^{14}$. Drugi obszar krytyki jest znacznie szerszy i silnie nacechowany emocjonalnie. Wcześni krytycy neopozytywizmu widzieli $\mathrm{w}$ nim reakcje przeciw filozofii materialistycznej ${ }^{15}$. Inni widzieli w logicznym empiryzmie nurt zdominowany przez Żydów, którzy chcieli wyplenić metafizykę z kultury jednego z najbardziej metafizycznie usposobionych narodów - Niemców ${ }^{16}$. Krytyka logicznego empiryzmu przybrała na sile zwłaszcza w latach 60. i 70. XX wieku w związku z rozwojem postmodernizmu i lewicowych prądów myślowych. Ten nurt krytyki stanowi kontynuację wyszukiwania winnych II wojny światowej, poprzez wskazywanie intelektualnych źródeł totalitaryzmu ${ }^{17}$. Krytycy ci dostrzegli w neopozytywistach propagatorów scjentyzmu i technokracji, które ich zdaniem

\footnotetext{
${ }^{14}$ W. Sady, Spór o racjonalność naukową. Od Poincarego do Laudana, Funna, Wrocław 2000; J. Woleński, Epistemologia, t. 1: Zarys historyczny i problemy metateoretyczne, Kraków 2000.

${ }^{15}$ Poglądy takie głoszone były głównie przez filozofów z nurtu marksistowsko-leninowskiego. Krytykę pozytywizmu jako wstecznych idei rozpoczął Włodzimierz Lenin krytyką empiriokrytycyzmu, z którego wyrósł bezpośrednio logiczny empiryzm. W. Lenin, Materializm a empiriokrytycyzm. Krytyczne uwagi o pewnej reakcyjnej filozofi, przekład z 5 wyd. rosyjskiego, [w:] W. Lenin, Dzieła wszystkie, t. 18, wyd. 2, Warszawa 1984, passim. Lenin krytykuje zwłaszcza cofnięcie filozofii do czasów Davida Hume’a i George’a Berkeleya. Zwolenników Ernsta Macha i jego kontynuatorów nazywał pogardliwie Machistami.

${ }^{16}$ „Żyd jest bowiem urodzonym antymetafizykiem, rozkochanym w filozofii logicyzmu, matematycyzmu, formalizmu i pozytywizmu [...]", Prof. Dr. Austriacus, Der Fall des Wiener Professors Schlick - eine Mahnung zur Gewissenserforschung „Das Neue Reich”, Wien XI 12 1936, s. 2. Cyt. za: A. Koterski, Geneza i cel naukowej koncepcji świata, [w:] Naukowa koncepcja świata..., s. 57. Cytowany artykuł był paszkwilem napisanym przez anonimowego autora po śmierci M. Schlicka, zasztyletowanego przez jednego z jego studentów, sympatyzującego $\mathrm{Z}$ nazistami.

${ }^{17}$ K. R. Popper, Społeczeństwo otwarte i jego wrogowie, t. 1: Urok Platona, przeł. A. Chmielewski, Warszawa 1993.
} 
przygotowały ideologiczny grunt pod rozwój nazizmu ${ }^{18}$. Osobnym nurtem krytyki jest współczesna filozofia nauki, która w logicznym empiryzmie upatruje zagrożenie dla metafizycznych spekulacji, zarzucając mu groźny dla rozwoju nauki dogmatyzm ${ }^{19}$.

Wszystkie kierunki krytyki odznaczają się ahistorycznością. Pierwszy z nich ocenia nurt logicznego empiryzmu z punktu widzenia współczesnego stanu wiedzy. O problemach związanych z uwspółcześnianiem refleksji nad historią filozofii i nauki wiele mówią wnioski z eksperymentu T. S. Kuhna ${ }^{20}$. Drugi nurt, poruszający znacznie szersze spektrum zagadnień ocenia logiczny empiryzm wedle pewnego ukształtowanego obrazu świata i jest daleki od obiektywizmu historycznego ze względu na swój emocjonalny charakter.

Jednym z najczęściej podnoszonych zarzutów była teza logicznych empirystów o potrzebie redukcji filozofii do roli narzędzia służącego analizie języka nauki. Przekonanie o tym, że wiedza naukowa dana jest w języku, miało dla logicznych empirystów znaczenie pierwszorzędne. Na jej podstawie można było założyć, że większość problemów da się rozstrzygnąć za pomocą analizy językowej ${ }^{21}$. Połączenie klasycznego empiryzmu z rozwijającą się filozofią logicyzmu miało zdaniem neopozytywistów zaowocować wypracowaniem narzędzi intelektualnych nowoczesnego empiryzmu, zdol-

\footnotetext{
${ }^{18}$ L. Kołakowski, dz. cyt., s. 10.

${ }^{19}$ W. Sady, dz. cyt.; J. Misiek, Dziedzictwo logicznego empiryzmu a problem podstaw matematyki, [w:] Dziedzictwo logicznego empiryzmu, pod red. M. Czarnockiej, Warszawa 1995; J. Życiński, W poszukiwaniu ideału nauki, [w:] Wszechświat - maszyna czy myśl? Filozofia mechanicyzmu: powstanie - rozwój - upadek, pod red. M. Hellera, J. Życińskiego, Kraków 1988, s. 267.

${ }^{20} \mathrm{Na}$ seminarium doktorskie z zakresu historii nauki prowadzone przez T. Kuhna uczęszczali w większości historycy i filozofowie. Kuhn obserwował ich różne podejście do omawianych zagadnień. Mimo że zarówno filozofowie, jak i historycy pracowali na tych samych tekstach klasycznych autorów, to owocem ich analizy były całkiem odmienne referaty. Najczęstszym błędem filozofów było uwspółcześnianie omawianych zagadnień. Trudno było się doszukiwać w referowanych tekstach zagadnień, do których odwoływali się autorzy analizowanych tekstów. Próby analizy tekstów autorów klasycznych przy odwoływaniu się do współczesnego rozumienia, czym jest nauka i jak się rozwija, powodowały zniekształcenia w poglądach, które chciał przekazać autor klasycznego tekstu. Inaczej mówiąc, starali się udoskonalić argumentację autora przy wykorzystaniu współczesnych osiągnięć nauki i filozofii. Referaty historyków, przyzwyczajonych do konstruowania argumentów, były krótkie, zwięzłe i ograniczały się do wypunktowania błędów. T. S. Kuhn, Dwa bieguny. Tradycja i nowatorstwo w badaniach naukowych, przeł. S. Amsterdamski, Warszawa 1985, s. 33-35.

${ }^{21}$ M. Schlick, Punkt zwrotny w filozofii, przeł. A. Marek, [w:] Empiryzm współczesny..., s. 16 [13-19].
} 
nego przezwyciężyć kryzys na gruncie nauki, życia społeczno-politycznego i gospodarczego 22 .

Czym wobec tego jest filozofia i jaką ma rolę zdaniem logicznych empirystów? Moritz Schlick twierdził, że filozofia nie jest nauką i nie jest systemem twierdzeń, jak - jego zdaniem - dotychczas uważano. Schlick określił zadania zreformowanej filozofii w swoim artykule Punkt zwrotny w filozofi, gdzie jej rolę widział w wyjaśnianiu zdań, które następnie miały być weryfikowane empirycznie ${ }^{23}$.

Kolejnym postulatem logicznych empirystów, który wywołał falę krytyki, było wyrugowanie tez metafizycznych poza nawias nauki. Neopozytywistyczny program walki z metafizyką był kontynuacją programu Hume'a, który swe Badania dotyczące rozumu ludzkiego zakończył znaną myślą, że prace nie zawierające rozumowań opartych na doświadczeniu i liczbach są nic nie wartą sofistyką i należy je spalić ${ }^{24}$. Pogląd ten był często przytaczany przez krytyków logicznego empiryzmu, którzy zarzucali im przygotowanie intelektualnego gruntu pod proces palenia ,szkodliwych” książek na stosach w 1933 roku.

Dlaczego problem ten wywołał tak wiele kontrowersji? Zdaniem Michała Hellera istnienie metafizyki w filozofii to kwestia być albo nie być filozofii. Bez metafizyki filozofia zostałaby sprowadzona do kilku szczegółowych dyscyplin zajmujących się analizą języka, ewentualnie refleksją nad metodologią nauk szczegółowych ${ }^{25}$.

Radykalizm logicznych empirystów, postulujących daleko idącą redukcję filozofii oraz oczyszczenie jej z metafizycznych naleciałości, stał się celem ataku ze strony ich krytyków, zarzucających im doktrynerstwo i ślepą walkę z metafizyką. $Z$ pewnością nie było to ślepe i bezsensowne zwalczanie tez, nie mających umocowania w empirii. Logiczni empiryści nie odrzucali tez metafizycznych jako błędnych czy szkodliwych. Przykładem mogą być twierdzenia o przyczynowości zjawisk czy teza o realnym istnieniu świata zewnętrznego. Dla logicznych empirystów twierdzenia te nie były fałszywe, lecz stanowiły ciąg wyrazów, których nie można zweryfikować w warunkach doświadczenia. Próbę logicznej analizy takich zdań, uważali za postępowanie pseudonaukowe, pozbawione sensu poznawczego, gdyż nie można

\footnotetext{
${ }^{22}$ Naukowa koncepcja świata ..., s. 76.

${ }^{23}$ M. Schlick, Punkt zwrotny..., s. 16-17.

${ }^{24}$ D. Hume, dz. cyt., s. 133.

${ }^{25}$ M. Heller, Metafizyka po pozytywizmie, „Zagadnienia Filozoficzne w Nauce, t. 22, 1998, s. 136 .
} 
ich poddać empirycznej weryfikacji. Stąd też Carnap, broniąc się przed zarzutami przeciwników, podkreślał, że doktryna logicznych empirystów jest natury logicznej i nie ma nic wspólnego ze zwalczaniem tez metafizycznych, ponieważ po prostu ich nie podejmuje ${ }^{26}$. Jak wobec tego można zdefiniować antymetafizyczne nastawienie neopozytywistów? Carnap uważał, że zdania metafizyczne, mimo iż są nienaukowe, odgrywają istotną rolę ogólnokulturową. Dlatego też zdania takie nie powinny być rozważane na gruncie nauki, gdyż nie zawierają wiedzy ani błędu i nie da się o nich dyskutować w kategoriach prawdy i fałszu ${ }^{27}$.

Równie wiele kontrowersji wzbudził także program fizykalizmu, polegającego na redukcjonistycznym uprawianiu nauki. Miał on na celu zastępowanie terminów nauk biologicznych i społecznych terminami fizycznymi, które zdaniem logicznych empirystów lepiej precyzowały opisywane zjawisko ${ }^{28}$.

Fizykalizm i w ogóle wszelki redukcjonizm były szczególnie krytykowane po II wojnie światowej. Neopozytywistom zarzucano propagowanie w społeczeństwie postawy technokratycznej. Zdaniem L. Kołakowskiego logiczny empiryzm, będąc aktem emancypacji od kłopotliwych pytań natury filozoficznej, miał na celu neutralizację nauki pod względem wartościującym, by uczynić z niej absolutne stanowisko obserwacyjne ${ }^{29}$.

Redukcjonizm w nauce zwalczali również filozofowie należący do szkoły frankfurckiej. Jej przedstawiciele twierdzili za Wilhelmem Dilthey'em, że sprowadzanie wszystkich dziedzin ludzkiej wiedzy do fizyki przeczy du-

${ }^{26}$ R. Carnap, Filozofia jako analiza języka nauki, przeł. A. Zabłudowski, Warszawa 1969, s. 13. Carnap podał następujący przykład: „O ile ze stwierdzenia, że istnieją kangury możemy dedukować zdania postrzeżeniowe, o tyle ze stwierdzenia, że świat fizyczny istnieje, żadnych zdań postrzeżeniowych wydedukować nie można; to samo dotyczy twierdzenia przeciwnego, głoszącego, że świat fizyczny realnie nie istnieje. Toteż oba te twierdzenia są pozbawione empirycznej treści - są pozbawione sensu”.

27 Tamże, s. 20-21.

${ }^{28}$ R. Carnap, Filozofia jako analiza..., s. 59-60. R. Carnap jako przykład proponuje analizę zdania: „O godzinie 10.00 Pan A był rozgniewany”. Równoważne treściowo zdanie w języku fizykalnym powinno brzmieć: „O godzinie 10.00 pan A, znajdował się w pewnym stanie fizycznym, który charakteryzował się przyspieszonym oddechem i pulsem, napięciem pewnych mięśni, skłonnością do gwałtownych reakcji”.

${ }^{29}$ L. Kołakowski, Filozofia pozytywistyczna..., s. 208. Krucjatę wypleniania scjentyzmu ze społecznego odbioru nauki rozpoczął Thomas S. Kuhn. W jego opinii ideologia ta przenikała do podręczników szkolnych, publikacji popularnonaukowych, gdzie kształtował się obraz nauki, jako zbioru technik doświadczalnych oraz operacji logicznych. T. S. Kuhn, Struktura rewolucji naukowych, przeł. H. Ostromęcka, Warszawa 2001, s. 20. 
chowi i zadaniom nauk, gdyż w ich opinii nauki dzielą się na wyjaśniające (przyrodoznawstwo) i rozumiejące (humanistyka). Szkoła frankfurcka zyskała dużą popularność po roku 1968. Krytyka scjentyzmu i technokracji, szybko przerodziła się w krytykę całej nauki, w której filozofowie krytyczni widzieli umocowanie dla technokratycznego porządku i państwa totalitarnego. Herbert Marcuse uważał, że nauka wskutek swej własnej metody i pojęć, sprzyja kształtowaniu się świata, w którym panowanie nad przyrodą związane jest z panowaniem nad człowiekiem ${ }^{30}$. Filozofowie krytyczni obwiniali kolejne trzy pozytywizmy (klasyczny, empiriokrytycyzm i empiryzm logiczny) o moralny upadek społeczeństwa i rozwój totalitaryzmu. Ich zdaniem, związany z pozytywizmem scjentyzm zaowocował eliminacją metafizyki z nauk szczegółowych, co doprowadziło do zaniku potrzeby wartościowania i braku refleksji wśród naukowców na temat ewentualnych skutków społecznych ich odkryć.

Dlaczego logiczni empiryści propagowali tak daleko idące zmiany w języku nauki? Potrzebę zjednoczonej nauki wyrażającej swe twierdzenia w języku fizykalnym Neurath uzasadniał możliwością intersubiektywnej zrozumiałości dla przedstawicieli różnych dyscyplin. Posługiwanie się rozbieżną terminologią przez różne szkoły filozoficzne, psychologiczne czy socjologiczne wywoływało nieporozumienia, brak zrozumienia dla pracy szkoły konkurencyjnej, co w ostateczności owocowało niemożnością prowadzenia konstruktywnej krytyki, która umożliwiłaby szybki postęp w tych dziedzinach, jaki znany był w fizyce dzięki ścisłości jej pojęćc ${ }^{31}$.

\footnotetext{
${ }^{30} \mathrm{H}$. Marcuse, Człowiek jednowymiarowy. Badania nad ideologia rozwiniętego społeczeństwa przemysłowego, przeł. S. Konopacki, Warszawa 1991, s. 31-32. Krytyka ideału nauki proponowanego przez logicznych empirystów, a szczególnie eliminacja psychologizmu i metafizyki, utożsamiana była $\mathrm{z}$ narodzinami technokracji, która $\mathrm{w}$ ich opinii była szczególnym zagrożeniem dla ludzkości. Eliminacja wielu niewygodnych i kłopotliwych idei przez skrajny empiryzm zaowocowała wzmocnieniem pozytywizmu, który jest ideologią pożądaną z punktu widzenia establishmentu przemysłowego, dążącego do zniewolenia społecznego. Zwłaszcza rozdział VII: „Triumf myślenia pozytywnego”.

${ }^{31}$ O. Neurath, Unifikacja nauki jako zadanie, przeł. A. Koterski, [w:] Naukowa koncepcja świata..., s. 206-213 [206-214]. R. Carnap, Język fizykalny jako uniwersalny język nauki, przeł. L. Kopciuch, [w:] Spór o zdania protokolarne..., ss. [7-36].
} 


\section{Doktrynerstwo czy postawa naukowa?}

W literaturze przedmiotu ukształtował się dominujący obraz logicznych empirystów, jako wysoko koherentnej grupy dogmatyków, którzy zwalczali wszelkie przejawy myślenia niezgodnego z ich wizją naukowej koncepcji świata $^{32}$. Głównym celem tej krytyki była chęć pozbawienia światopoglądu naukowego dominującej roli w cywilizacji zachodniej. Determinację przeciwników tego nurtu najlepiej obrazują słowa P. K. Feyerabenda, który pisał: ,[...] walkę o tolerancję i postęp w nauce należy jeszcze kontynuować. Zmieniła się tylko nazwa wrogów. Kilka dziesięcioleci temu byli nimi księża, czy filozofowie skupieni w szkołach. Dziś nazywają oni siebie „filozofami nauki” lub „logicznymi empirystami”"33.

Podstawowy problem z dotychczasową krytyką tego nurtu, wiąże się $\mathrm{z}$ traktowaniem go, jako tradycyjnie pojmowanego systemu filozoficznego, co jest sprzeczne z postulatami jego twórców. Należy wobec tego postawić pytanie, czy logiczny empiryzm należy traktować jak typową szkołę czy też system filozoficzny? Z lektury podręczników do historii filozofii wynika, że tradycyjne systemy, przechodząc wszystkie etapy swego rozwoju, dochodzą ostatecznie do fazy skostniałego dogmatyzmu, w którym ich przedstawiciele nie są już w stanie sami dostrzec zasadniczych błędów założeń swojej szkoły. Dostrzeżenie tych błędów oraz ich krytyka przypada już w udziale następnemu pokoleniu myślicieli, którzy najczęściej rozwijają swoje tezy w opozycji do dotychczas panującego systemu.

Powszechnie uważa się, że ,grabarzem” logicznego empiryzmu był Karl Popper. Filozof ten miał największy wpływ na jego współczesne rozumienie, nazywając ten nurt, „głęboko zakorzenionym przesądem i złudzeniem, które utrudnia rozumienie metody naukowej"34. Popper rozwijał swój program

\footnotetext{
${ }^{32}$ Przykładem takiego pojmowania logicznego empiryzmu może być opinia L. Kołakowskiego: „Od początku empiryzm logiczny miał wyraźny charakter szkoły, świadomej własnej odrębności, dysponującej wspólnie uznanymi założeniami, wspólnie atakującej stanowiska przeciwne; do cech tego kierunku jako 'szkoły' właśnie należał również jej język agresywny i gwałtowny, sekciarski nieco i apodyktyczny styl, niewzruszone przekonanie o radykalnym charakterze przewrotu, jaki dzięki niej dokonuje się w dziejach myśli, absolutna pewność własnej racji i głębokie przeświadczenie o ogromnej misji w kulturze, nietolerancja wobec odmiennych przekonań". L. Kołakowski, Filozofia pozytywistyczna..., s. 183.

${ }^{33}$ P. K. Feyerabend, Jak być dobrym empirystą..., s. 25. W komentarzu do tej myśli Feyerabend poszerza zakres wrogów postępu również o filozofię analityczną.

${ }^{34}$ K. R. Popper, Droga do wiedzy. Domysty i refutacje, przeł. S. Amsterdamski, Warszawa 1999, s. 213.
} 
racjonalizmu krytycznego, stając w opozycji do podstawowych założeń logicznego empiryzmu. Swoje spotkania i dyskusje z przedstawicielami Koła Wiedeńskiego wspominał jako czas krystalizacji jego własnego programu filozoficznego: „Było dla mnie oczywiste, że ludzie ci poszukiwali kryterium demarkacji nie tyle nauki od pseudonauki, ile nauki od metafizyki. Było dla mnie również jasne, że moje stare kryterium demarkacji było lepsze od pro-

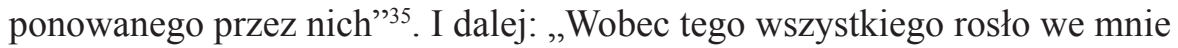
poczucie, że na każdy ich główny problem mam lepsze i bardziej koherentne odpowiedzi niż oni sami" ${ }^{36}$.

Czy zarzut doktrynerstwa i nieliczenia się z argumentami przeciwników stawiany przez wielu krytyków trzeciego pozytywizmu jest słuszny? Kilka faktów historycznych wskazuje na to, że i ten zarzut jest nieuzasadniony. Wśród historyków filozofii panuje powszechne przekonanie, że proces upadku programu logicznych empirystów przebiegał stopniowo. Składały się na niego kolejne publikacje obnażające słabość neopozytywistycznej wizji nauki. Za przełomowe w procesie jego obalania najczęściej uznaje się dwie prace. Logike odkrycia naukowego Karla Poppera (1934), oraz Strukture rewolucji naukowych Thomasa Kuhna (1962). Praca Poppera powstała jako krytyka poglądów logicznych empirystów i spotkała się z zainteresowaniem członków Koła. Jeden z nich - Herbert Feigl powiedział Popperowi, że jego poglądy są rewolucyjne i powinien je opublikować w formie książki ${ }^{37}$. Jej ostateczna wersja - wedle relacji Poppera okrojona o połowę przez redakcję - została opublikowana w serii wydawniczej, którą redagowali członkowie Koła - Moritz Schlick i Philipp Frank.

Druga publikacja, autorstwa Kuhna, również uznawana za gwóźdź do trumny logicznego empiryzmu, została opublikowana z inicjatywy Koła Wiedeńskiego. Ukazała się, jako monografia stanowiąca część większej serii wydawniczej, funkcjonującej jako projekt Koła pod tytułem „Międzynarodowej Encyklopedii Zjednoczonej Nauki" "38.

Karl Popper, który w wielu podręcznikach historii filozofii jest mylnie zaliczany do członków lub zwolenników Koła Wiedeńskiego ${ }^{39}$, jako pierwszy

${ }^{35}$ K. R. Popper, Nieustanne poszukiwania. Autobiografia intelektualna, przeł. A. Chmielewski, Kraków 1997, s. 109-110.

${ }^{36}$ Tamże, s. 110.

37 Tamże, s. 112.

${ }^{38}$ W. Sady, Spór o racjonalność naukową..., s. 74.

${ }^{39}$ H. Buczyńska-Garewicz, dz. cyt., s. 7. R. Ingarden, Z badań nad filozofia współczesną, Warszawa 1963, s. 648. Sam Popper utrzymuje, że nigdy nie został zaproszony na czwartkowe 
rozpoczął proces długiego obnażania słabości logicznego empiryzmu. On sam również widzi siebie w roli „grabarza” tego nurtu: „Wszyscy wiedzą, że pozytywizm logiczny jest martwy. Nikt jednak nie sądzi, że wypada w tym miejscu zadać pytanie 'Kto jest za to odpowiedzialny?' czy raczej: 'K to to zrobił?' Obawiam się, że to ja muszę przyznać się do odpowiedzialności za ten czyn" ${ }^{40}$.

Ale czy rzeczywiście Popper samodzielnie obalił logiczny empiryzm? Czy w przypadku logicznego empiryzmu potwierdza się utarty schemat, że podstawowe założenia systemu filozoficznego, który nieubłaganie zmierza do fazy dogmatycznej, są w stanie obalić tylko filozofowie stojący do niego w opozycji? Ostrożniejszą tezą byłoby twierdzenie, że logiczni empiryści, konsekwentnie stosując postulowaną przez siebie postawę naukową, sami obnażyli słabości swego programu. Rozważmy dwa główne założenia logicznego empiryzmu. Po pierwsze, nurt ten czerpał inspirację z rozwijającego się na przełomie XIX i XX wieku na gruncie filozofii matematyki logicyzmu, który poszukiwał recepty na trudności związane z problemem samoodniesienia języka.

Problem ten próbowały rozwiązać kolejne pokolenia matematyków i logików od Giuseppe Peano przez Gottloba Fregego, Davida Hilberta po Bertranda Russela i Kurta Gödla. Rozwiązaniem miał być program aksjomatyzacji, obejmujący arytmetykę liczb naturalnych, który miał jej nadać doskonałość, jaką mogła się szczycić od kilkudziesięciu wieków geometria zaksjomatyzowana przez Euklidesa. Ich zamierzeniem było sprowadzenie matematyki do kilku „samooczywistych” zasad logiki, z których następnie można by było dedukować twierdzenia matematyki ${ }^{41}$. Mając przykład geometrii uważali, że cel taki jest możliwy do zrealizowania. Już Frege uważał, że zamierzony przez niego program redukcji arytmetyki do logiki dowodzi jej analityczności ${ }^{42}$.

seminarium Schlicka. Spotykał się jednak w mieszkaniach poszczególnych członków Koła, gdzie przedstawiał swoją krytykę programu logicznego empiryzmu. K. R. Popper, Nieustanne poszukiwania..., s. 114-115.

${ }^{40}$ K. R. Popper, Nieustanne poszukiwania...., s. 120.

${ }^{41}$ Nie będę tu przybliżał idei logicyzmu, gdyż został już wyczerpująco przedstawiony w literaturze. Zob. E. Nagel, J. R. Newman, Twierdzenie Gödla, przeł. B. Stanosz, Warszawa 1966, s. 10; R. Murawski, Główne koncepcje i kierunki filozofii matematyki XX wieku, „Zagadnienia Filozoficzne w Nauce", t. 33, 2003, s. [74-92].

${ }^{42}$ G. Frege, Fragmenty $z$ Die Grundladen der Arithmetik, przeł. B. Wolniewicz, [w:] tenże, Pisma semantyczne, Warszawa 1977, s. 10-12 [10-17]. 
Nadzieje na uzyskanie kilku gruntownych zasad, na których można by oprzeć gmach nauk formalnych, okazały się mirażem już w 1931 roku. Wtedy to jeden z założycieli Koła Wiedeńskiego - Kurt Gödel zawarł w swym artykule tezy, które przeczyły możliwości realizacji takiego programu. Wykazał słabość metody aksjomatycznej, udowadniając, że nawet zwykła arytmetyka liczb naturalnych nie może zostać w pełni zaksjomatyzowana. Twierdził, że nawet jeśli udałoby się taki aksjomatyczny system stworzyć, to nie można by udowodnić jego zupełności i wewnętrznej niesprzeczności ${ }^{43}$.

Zasadniczy problem logicznych empirystów z poszukiwaniem pewnej podstawy dla ich programu rozbijał się o podstawową kwestię. Nie można było sprowadzić matematyki do logiki, ponieważ liczb naturalnych nie można zdefiniować w ramach logiki. Zostały one wprowadzone do matematyki, jako aksjomaty ${ }^{44}$. Wobec tego program redukcjonistyczny w tym obszarze okazał się niemożliwy do realizacji. Ich założenie o pewności matematycznych twierdzeń stało się metafizyczną tezą, której nie można było empirycznie zweryfikować.

Drugim podstawowym założeniem logicznego empiryzmu było twierdzenie, że wiedza naukowa ma pochodzenie zmysłowe. Stąd też drugim naczelnym postulatem była eliminacja twierdzeń nie mających poparcia w doświadczeniu. Odkrycie dowodu na nierealność tego postulatu również przypadło w udziale uczonemu sympatyzującemu z neopozytywistycznym ideałem nauki. Niemożliwość wyrugowania metafizyki z teorii naukowych udowodnił przedstawiciel szkoły lwowsko-warszawskiej - Henryk Mehlberg ${ }^{45}$. Jego odkrycie dotyczyło zwłaszcza praw przyrody, które w zdaniach je opisujących zawierają wyrażenia „każdy”, ,zawsze”, „ilekroć”. Aby na przykład zweryfikować empirycznie zdanie „Dla każdego gazu istnieje temperatura, przy której żadne podwyższenie jego ciśnienia nie skropli go"46, konieczne stałoby się przeprowadzenie nieskończonego szeregu obserwacji,

\footnotetext{
${ }^{43}$ E. Nagel, J. R. Newman, dz. cyt., s. 10.

${ }^{44}$ J. Misiek, dz. cyt., s. 126.

${ }^{45}$ Dla Mehlberga wypowiedzi niesprawdzalne stanowią nieodłączną i konieczną część teorii naukowych, nawet przy założeniu, że możliwość uprawdopodobnienia takiego zdania wymagałaby nieskończonego szeregu obserwacji. Zdania takie tworzą zewnętrzną bazę nauki, bez której jest ona niemożliwa. Por. H. Mehlberg, O niesprawdzalnych założeniach nauki, [w:] Logiczna teoria nauki. Wybór artykułów, pod red. T. Pawłowskiego, Warszawa 1966, s. 341$-343,358-359$ [341-361].

${ }^{46}$ Przykład taki analizuje dokładnie H. Mehlberg, dz. cyt., s. 346-347.
} 
przy którejś z kolei obserwacji mogłoby bowiem dojść do złamania tego prawa.

W świetle powyższych dwóch przykładów nasuwa się wniosek, że dzięki uporowi w dążeniu do naukowej prawdy logiczni empiryści sami doszli do wniosku, że metafizyczne zdania ${ }^{47}$, czy aksjomaty matematyki stanowią wedle terminologii Mehlberga - zewnętrzną bazę nauki, która jest nieweryfikowalna empirycznie, a bez której nauka nie może istnieć. Stąd wniosek, że logiczni empiryści sami obnażyli słabość swego programu.

\section{Podsumowanie}

Trudno doszukiwać się w logicznym empiryzmie cech tradycyjnego systemu czy też szkoły filozoficznej, która przechodzi wszystkie etapy rozwoju, by dojść do fazy dogmatycznej, w której przeciwnicy wykazują zasadniczą błędność jego podstawowych założeń. Bliższe prawdzie jest traktowanie tego nurtu, jako specyficznej postawy naukowej, czy też zbioru postulatów metodologicznych.

Za takim ujęciem tego nurtu przemawiają również wypowiedzi członków Koła, którzy wielokrotnie powtarzali, że ich celem nie jest tworzenie nowej szkoły filozoficznej. W manifeście Koła autorzy określili swoje zamierzenia:

Naukową koncepcję świata stanowią nie tyle jej tezy, lecz raczej zasadnicza postawa, jej punkty widzenia i kierunek badań. Celem jaki należy osiągnąć jest zunifikowana nauka. Przedsięwzięcie to polega na połączeniu i zharmonizowaniu osiągnięć poszczególnych badaczy z rozmaitych dziedzin nauki. Ze względu na ten cel, nacisk kładzie się na wysiłek kolektywny, a także na to, co można ująć intersubiektywnie; stąd wypływają próby odnalezienia neutralnego systemu formuł, symboliki oswobodzonej spod hałdy języków historycznych [...]. Pożądane są czystość i jasność, odrzucone zaś zostają mroczne przestrzenie i niedające się pojąć głębie $[\ldots]^{48}$.

Zdaniem logicznych empirystów ich program nie był kontynuacją tradycyjnej filozofii systemowej. Nie wysuwali oni żadnych twierdzeń filozoficznych. Rozwijając naukową koncepcję świata, ograniczyli rolę filozofii do

\footnotetext{
${ }^{47}$ Mam tu na myśli przede wszystkim metafizyczną tezę o realnie istniejącej rzeczywistości fizycznej, bez której nie mogłaby się obejść naczelna zasada logicznych empirystów, czyli zasada empirycznej weryfikowalności twierdzeń naukowych.

${ }^{48}$ Naukowa koncepcja świata..., s. 76-77.
} 
objaśniania pojęć nauk szczegółowych ${ }^{49}$. Logiczna analiza zdań teorii miała na celu uwolnienie nauki od pojęć niezrozumiałych. Dalszymi celami były intersubiektywna zrozumiałość poszczególnych dziedzin wiedzy, co miało zaowocować łatwiejszym dostępem nowych odkryć naukowych w odbiorze społecznym, oraz wzrost kultury umysłowej społeczeństwa, które przez system edukacji, miałoby stać się nosicielem naukowej postawy.

Ostatni postulat brzmi idealistycznie. Jednak trzeba mieć na względzie realia historyczne, w których rozwijał się logiczny empiryzm i fakt, że postawa naukowa była dziełem ludzi, żyjących w określonej epoce, czytających ówczesne gazety, kontemplujących sztukę, literaturę i architekturę modernizmu. Również umysłowość tego okresu wyrażała się w dążeniu do prostoty i zrozumiałości. Skąd logiczni empiryści czerpali ufność, że ich program znajdzie oddźwięk w odbiorze społecznym? Carnap tłumaczył to czymś, co Niemcy zwykli nazywać duchem czasu:

Odczuwamy wewnętrzne pokrewieństwo postawy leżącej u źródeł naszego uprawiania filozofii z postawą duchową, która występuje obecnie w innych dziedzinach życia. Wyczuwamy tę postawę w nurtach sztuki, zwłaszcza w architekturze, i w ruchach, które poszukują znaczących kształtów ludzkiego życia osobistego i zbiorowego, wychowania i w ogóle zewnętrznych struktur. Wszędzie tam wyczuwamy przede wszystkim tę samą postawę, ten sam styl myślenia i działania. Jest to orientacja, która zmierza przede wszystkim do jasności, zdając sobie jednak przy tym sprawę, że materia życia nigdy nie zostanie poznana na wskros ${ }^{50}$.

Roman Ingarden, analizując sytuację współczesnej mu filozofii, postawił diagnozę, zgodnie z którą nurty filozoficzne wzrastają i upadają w związku ze zmianami psychicznej postawy wobec rzeczywistości, a zmiany te najczęściej wiążą się z doniosłymi wydarzeniami politycznymi ${ }^{51}$. W początkach XX wieku wydarzeniem, które najsilniej wpłynęło na zmiany psychicznej postawy wobec rzeczywistości była wojna, która wybuchła w 1914 roku.

Minimalistyczny program logicznych empirystów cieszył się dużą popularnością wśród elit intelektualnych Europy okresu międzywojennego. Ludzie zmęczeni Wielkim Kryzysem trwającym od 1929 roku, zrażeni nacjo-

\footnotetext{
49 Tamże, s. 91-92.

${ }^{50}$ R. Carnap, Logiczna struktura świata, przeł. P. Kawalec, Warszawa 2011, s. CXIV [przedmowa do wydania pierwszego].

${ }^{51}$ R. Ingarden, dz. cyt., s. 643.
} 
nalizmem, który doprowadził do I wojny światowej oraz rozwijającymi się ideologiami, zarówno prawicowymi, jak i lewicowymi, poszukiwali filozofii, która nie szermuje wielkimi hasłami, posługuje się prostym i zrozumiałym językiem, a każde słowo ma swój stały i określony sens. Neopozytywiści zalecali umiarkowane i staranne ważenie każdego wypowiadanego słowa. Wierzyli, że w nauce oczyszczonej z metafizyki nie znajdzie oparcia żadna ideologia. Upowszechnienie postawy naukowej, nauczenie ludzi odpowiedzialności za wypowiadane twierdzenia miało przyczynić się do wzrostu kultury umysłowej ogółu społeczeństwa.

Idee przyświecające realizacji programu neopozytywistycznego były w swych założeniach idealistyczne. Oddzielenie tego, co może ubiegać się o miano nauki od metafizyki i złudzeń, miało zaowocować wyplenieniem z życia społecznego przesądów i fanatyzmu. Filozofia ta była, można by rzec, potrzebą chwili, zwłaszcza w obliczu rosnącej popularności nazizmu i komunizmu, które bazując na eugenice czy materializmie dialektycznym, pretendowały do miana naukowych, szukając w ten sposób uprawomocnienia dla swych racji.

Ostatecznie realizację programu reformy nauki postulowanej przez neopozytywistów przerwało dojście Hitlera do władzy i Anschluss Austrii. Większość logicznych empirystów, będąca Żydami i sympatyzująca z socjaldemokracją, emigrowała do Stanów Zjednoczonych. Podobny los spotkał inne ośrodki neopozytywizmu w kontynentalnej Europie. Do USA przenieśli się między innymi przedstawiciele szkół berlińskiej i lwowsko-warszawskiej.

Zdaniem Romana Ingardena stopień radykalizmu nowej umysłowości zawsze jest proporcjonalny do skali wstrząsu, który spowodował przemiany w psychice ludzi ${ }^{52}$. Kolejną zmianę w psychicznej postawie społeczeństwa spowodowała II wojna światowa. Wraz z ujawnieniem wszystkich jej okropieństw, zrodziła się nowa umysłowość, której owocem były nowe nurty filozofii, radykalnie przeciwne wobec czołowego kierunku epoki minionej. $\mathrm{Z}$ tego też powodu całe ostrze krytyki skupiło się na logicznym empiryzmie.

${ }^{52}$ Tamże. 


\section{Bibliografia}

Buczyńska-Garewicz H., Koło Wiedeńskie, Toruń 1993.

Carnap R., Język fizykalny jako uniwersalny język nauki, przeł. L. Kopciuch, [w:] Spór o zdania protokolarne. „Erkenntnis” i „Analysis” 1932-1940, wybór i oprac. A. Koterski, Warszawa 2000.

Carnap R., Logiczna struktura świata, przeł. P. Kawalec, Warszawa 2011.

Carnap R., Przezwyciężenie metafizyki przez logiczna analize języka, przekład anonimowy, [w:] Empiryzm współczesny, wybór i oprac. B. Stanosz, Warszawa 1991.

Carnap R., Wprowadzenie do filozofii nauki, przeł. A. Koterski, Warszawa 2000.

Feyerabend P. K., Jak być dobrym empirystą?, przeł. K. Zamiara, Warszawa 1979.

Feyerabend P. K., Przeciw metodzie, przeł. K. Zamiara, Wrocław 2001.

Frege G., Fragmenty z Die Grundladen der Arithmetik, przeł. B. Wolniewicz, [w:] Frege G., Pisma semantyczne, Warszawa 1977.

Frege G., Myśl. Studium logiczne, przeł. B. Wolniewicz, [w:] Frege G., Pisma semantyczne, Warszawa 1977.

Einstein A., O elektrodynamice ciał w ruchu, przeł. P. Amsterdamski, [w:] A. Einstein, 5 prac, które zmieniły oblicze fizyki, Warszawa 2005.

Heller M., Metafizyka po pozytywizmie, „Zagadnienia Filozoficzne w Nauce”, t. 22, 1998.

Hume D., Badania dotyczace rozumu ludzkiego, przeł. D. Misztal, T. Sieczkowski, Kraków 2006.

Ingarden R., Z badań nad filozofia wspótczesną, Warszawa 1963.

Kołakowski L., Filozofia pozytywistyczna. Od Hume’a do Koła Wiedeńskiego, wyd. 2, Warszawa 2003.

Koterski A., Geneza i cel naukowej koncepcji świata, [w:] Naukowa koncepcja świata. Koło Wiedeńskie, pod red. A. Koterskiego, Gdańsk 2010.

Koterski A., Weryfikacjonistyczne kryteria demarkacji w filozofii nauki Koła Wiedeńskiego, Lublin 2001.

Kuhn T. S., Dwa bieguny. Tradycja i nowatorstwo $w$ badaniach naukowych, przeł. S. Amsterdamski, Warszawa 1985.

Kuhn T. S., Struktura rewolucji naukowych, przeł. H. Ostromęcka, Warszawa 2001.

Laudan L., Zgon problemu demarkacji, przeł. A. Koterski, [w:] Z badań nad nauka, prawda i poznaniem, pod red. Z. Muszyńskiego, Lublin 1998.

Lenin W., Materializm a empiriokrytycyzm. Krytyczne uwagi o pewnej reakcyjnej filozofii przekład z 5 wyd. rosyjskiego, [w:] W. Lenin, Dzieła wszystkie, t. 18, wyd. 2, Warszawa 1984.

Marcuse H., Człowiek jednowymiarowy. Badania nad ideologia rozwiniętego społeczeństwa przemysłowego, przeł. S. Konopacki, Warszawa 1991.

Mehlberg H., O niesprawdzalnych założeniach nauki, [w:] Logiczna teoria nauki. Wybór artykułów, pod red. T. Pawłowskiego, Warszawa 1966. 
Misiek J., Dziedzictwo logicznego empiryzmu a problem podstaw matematyki, [w:] Dziedzictwo logicznego empiryzmu, pod red. M. Czarnockiej, Warszawa 1995.

Murawski R., Główne koncepcje i kierunki filozofii matematyki XX wieku, „Zagadnienia Filozoficzne w Nauce", t. 33, 2003.

Naukowa koncepcja świata. Koło Wiedeńskie, pod red. H. Hahna, O. Neuratha, R. Carnapa, przeł. A. Koterski, [w:] Naukowa koncepcja świata. Koło Wiedeńskie, pod red. A. Koterskiego, Gdańsk 2010.

Neurath O., Zdania protokolarne, przeł. A. Koterski, [w:] Spór o zdania protokolarne. „Erkenntnis” $i$ „Analysis” 1932-1940, wybór i oprac. A. Koterski, Warszawa 2000.

Neurath O., Unifikacja nauki jako zadanie, przeł. A. Koterski, [w:] Naukowa koncepcja świata. Koło Wiedeńskie, pod red. A. Koterskiego, Gdańsk 2010.

Nagel E., Newman J. R., Twierdzenie Gödla, przeł. B. Stanosz, Warszawa 1966.

Newton I., Matematyczne zasady filozofii przyrody, przeł. J. Wawrzycki, Kraków 2011. Planck M., Pozytywizm a realny świat zewnętrzny, przeł. R. i S. Kernerowie, [w:] Planck M., Jedność fizycznego obrazu świata. Wybór pism filozoficznych, Warszawa 1970.

Popper K. R., Droga do wiedzy. Domysty i refutacje, przeł. S. Amsterdamski, Warszawa 1999.

Popper K. R., Logika odkrycia naukowego, przeł. U. Niklas, Warszawa 2002.

Popper K. R., Nieustanne poszukiwania Autobiografia intelektualna, przeł. A. Chmielewski, Kraków 1997.

Popper K. R., Społeczeństwo otwarte i jego wrogowie, t. 1: Urok Platona, przeł. A. Chmielewski, Warszawa 1993.

Sady W., Spór o racjonalność naukową. Od Poincarego do Laudana, Wrocław 2000.

Schlick M., Punkt zwrotny w filozofii, przeł. A. Marek, [w:] Empiryzm współczesny, wybór i oprac. B. Stanosz, Warszawa 1991.

Wittgenstein L., Tractatus Logico-Philosophicus, przeł. B. Wolniewicz, wyd. 3, Warszawa 2000.

Woleński J., Epistemologia, t. 1: Zarys historyczny i problemy metateoretyczne, Kraków 2000.

Życiński J., W poszukiwaniu ideału nauki, [w:] Wszechświat - maszyna czy myśl? Filozofia mechanicyzmu: powstanie - rozwój - upadek, pod red. M. Hellera, J. Życińskiego, Kraków 1988.

\section{Abstract}

Historical Conditions of the Development of Logical Empiricism and Ahistorical his Previous Criticism

In this paper examines the historical circumstances of the birth and development of logical empiricism. Its main objectives are shown in the background positions critical 
to this trend. The main conclusion that can be drawn from a paper, is the thesis that this trend should not be considered as traditionally conceived philosophical school. Recognition of it this way was the primary cause of ahistorical his previous criticism. Closer to the truth is that logical empiricism, formed in specific historical reality, is a specific scientific attitude or set of methodological postulates, formed in the face of crisis, the major areas of public life 20 and 30 years of the twentieth century.

Key words: empirism, analytic philosophy, physicalism, Vienna Circle, logical empiricism, logicism, mataphysics, scientism, reductionism 